Creative commons User License: CC BY-NC-ND

Abstracted by: EBSCOhost, Electronic Journals Service (EJS),

Google Scholar, Journal Seek, Scientific Commons,

Food and Agricultural Organization (FAO), CABI and Scopus
Journal of Agricultural Extension

Vol. 22 (2) June, 2018

ISSN(e): 24086851; ISSN(Print); 1119944X

http://journal.aesonnigeria.org

http://www.ajol.info/index.php/jae

Email: editorinchief@aesonnigeria.org

\title{
E-Readiness of Public Extension Personnel for Service Delivery in Benue State, Nigeria https://dx.doi.org/10.4314/jae.v22i2.10
}

\section{Olaolu Micheal 0.}

Department of Agricultural Extension, University of Nigeria, Nsukka, Enugu State

Email:michealolaolu@yahoo.com* Phone: +2348065489702;

\section{Agwu Ekwe A.}

Department of Agricultural Extension, University of Nigeria, Nsukka, Enugu State

Email:ekwe.agwu@unn.edu.ng Phono: +2348034024251

\section{Ivande Pauline D.}

Department of Home Science and Management, University of Agriculture, Makurdi, Benue

State, Nigeria

Email:ivandepd@yahoo.com Phono: +2348035059007

\section{Olaolu Tochukwu A.}

General Studies Unit, Godfrey Okoye University Enugu, Enugu State

Email:amytochy@yahoo.com Phone: +2347032211532

\section{Abstract}

This study assessed the e-readiness of the public extension personnel in Benue State of Nigeria for effective extension service delivery. Data were collected from seventy-seven (77) personnel randomly sampled. Frequency counts, percentages and mean scores were used to summarize the data collected while e-readiness index was used to assess the overall readiness of the personnel. Result reveals that the majority (74.0\%) had HND/ First degree as their highest educational qualification, with an average of 28 years work experience. The technologies available to personnel were alternative power generator (97.4\%), computers (72.2\%) and e-library (58.4\%). The majority $(76.6 \%)$ of the respondents opined that their computers were not in functional state. On their proficiency of computer usage, power point presentation ( $M=$ 2.00), email operation $(M=2.00)$ and excel spread sheet $(M=2.00)$ had the highest perceived proficiency. Public extension personnel in the State were barely ready on the resources available $(R A=1.97)$ and not ready on the accessibility to ICT $(A I C T=1.35)$ and barely ready based on their perceived quality of ICTS (PQICT = 1.69), as well as perceived importance of ICTS $(P I I C T=2.14)$ on the adherence to policies and regulations, they were barely ready $(P \& R=1.93)$. In all public extension personnel in Benue State were barely ready (e-readiness $=1.816$ ). The study among other things recommends among other things that the extension administrative staff should encourage the use of emails in exchanging information among staff.

Keywords: E-readiness, public extension personnel, information and communication tools 
Creative commons User License: CC BY-NC-ND

Abstracted by: EBSCOhost, Electronic Journals Service (EJS),

Google Scholar, Journal Seek, Scientific Commons,

Food and Agricultural Organization (FAO), CABI and Scopus
Journal of Agricultural Extension

Vol. 22 (2) June, 2018

ISSN(e): 24086851; ISSN(Print); 1119944X

http://journal.aesonnigeria.org

http://www.ajol.info/index.php/jae

Email: editorinchief@aesonnigeria.org

\section{Introduction}

Information and Communication Technology (ICT) is an indispensable part of the contemporary world. The use of information and communication technology (ICT) is becoming progressively more widespread throughout various sectors including education and other businesses such as agriculture. The frontline extension workers who are the direct link between farmers and other actors in the extension of agricultural knowledge and information systems are well positioned to make use of ICT to access expert knowledge or other types of information that could facilitate the accomplishment of farmers' routine activities (Omotayo, 2005). The maximisation of the benefits from ICTs is largely dependent on technical know-how as well accessibility to the new evolving ones. However, the increase in the digital divide between the developed and developing countries is as a result of ease of the developed countries to access new technologies as well as usage of ICT it whereas it is not so with developing countries. This is majorly as a result of how electronic ready (e-readiness) these countries are or have been.

The Asian Pacific Economic Cooperation (APEC) (2000) defined e-readiness as the degree to which an economy or community is prepared to participate in the digital economy, also, Zaied, Khairalla \& Al-Rashed (2007) defined e-readiness as the degree to which a community is prepared to participate in the information age (networked world). E-readiness is measured by assessing a community's relative advancement in the areas that are most critical for ICT adoption and the most important applications of ICT. E-readiness assessment is meant to guide development efforts by providing benchmarks for comparison and gauging progress. It can also be a vital tool for judging the impact of ICT, to replace wild claims and anecdotal evidence about the role of ICT in development with concrete data for comparison. The e-readiness assessment analyses the preparedness of a community to participate in the global information society and digital economy. The level of e-readiness is gauged by assessing maturity across a series of ICT indicators that are considered key in facilitating community development and delivering broad ICT-related benefits (Belize National ICT Policy, 2007).

The assessment of perception of stake holders is based on assessing the opinion of staff of such an organization on integrating ICT in to their work process. The usage of ICT facilities would be assessed based on the deployment of ICT facilities in information gathering, data processing, information dissemination, information storage, use of internet to communicate between staff, as well as the outreach to farmers.

Agricultural extension agencies are organizations saddled with the responsibility of planning and executing agricultural extension programmes to farmers to improve the farmers' production and productivity. These agencies could be public or private agencies. An example of a public extension agency is the Agricultural Development Programme (ADP). The ADPs represent a truly innovative approach to agricultural and rural development both in their integrated supply of farm inputs and infrastructural support and in their efforts to revamp and revitalize extension services 
Creative commons User License: CC BY-NC-ND

Abstracted by: EBSCOhost, Electronic Journals Service (EJS),

Google Scholar, Journal Seek, Scientific Commons,

Food and Agricultural Organization (FAO), CABI and Scopus
Journal of Agricultural Extension

Vol. 22 (2) June, 2018

ISSN(e): 24086851; ISSN(Print); 1119944X

http://journal.aesonnigeria.org

http://www.ajol.info/index.php/jae

Email: editorinchief@aesonnigeria.org

(Olugboyega and Olayiwola, 2005 in Olaolu, 2011). These ADPs exist in all the 36 states including the federal capital territory (FCT) in Nigeria.

In Benue State, it exists as Benue Agricultural and Rural Development Authority(BNARDA), and it coordinates most of the agricultural activities in the state. According to BNARDA (2005) its overall objective is to promote increased agricultural production in the state and raise the incomes and standard of living of the farmers. Its operations are organized into three core sub-programmes namely: agriculture, engineering and commercial services. There are also four support subprogrammes namely, administration, finance, human resource development and planning and evaluation. In order to make the impact of BNARDA felt in the whole state it is operated on the basis of three agro-development zones, namely, Eastern Zone (Zone A) with the headquarters located at Adikpo, Northern zone (Zone B) with the headquarters at Gboko and Central Zone (Zone $\mathrm{C}$ ) with the headquarters at Otukpo (Ogbonna, 2011).

Focusing on how agricultural extension can harness ICTs for improving rural livelihoods requires a broader of ICT use in agriculture beyond the ICT applications use only. This change in focus may result in a recognition that any ICT intervention that improves the livelihoods of poor rural families will likely have significant direct and indirect impacts in enhancing agricultural production, marketing and postharvest activities which in turn can further contribute to poverty reduction (Richardson, 2006). These have made several of the studies carried out on ICT in agricultural extension to focus majorly on only the perception of the users (extension personnel and farmers) on availability, access, utilization of ICT and agricultural development and perceived importance as well as possible constraints to ICT use by the users.

But the benefits that arise from ICT are dependent on the degree to which such a community, country, nation or economy/sector (agency) is ready, willing or prepared to obtain the benefits, this in simple form is the e-readiness. The measure of the ereadiness of any economy is often used to gauge how ready that economy is to partake in the electronic activities such as e-commerce, e-agriculture, e-learning and e-government (Dada, 2006). To put ICT to effective use, a nation or organisation should be electronically ready (e-ready). This therefore means that for ICT to make any significant impact on enhancing agricultural production, marketing and postharvest activities which in turn can further contribute to poverty reduction, the agricultural extension agencies, must be e-ready. This study therefore sought to assess how electronically ready the public agricultural extension agency in Benue State is for effective extension service delivery.

\section{Purpose of the study}

The overall purpose of the study was to assess the e-readiness of public extension personnel for service delivery in Benue State, specifically the study sought to:

1. identify the ICT resources (both human and material) available; 
Creative commons User License: CC BY-NC-ND

Abstracted by: EBSCOhost, Electronic Journals Service (EJS),

Google Scholar, Journal Seek, Scientific Commons,

Food and Agricultural Organization (FAO), CABI and Scopus
Journal of Agricultural Extension

Vol. 22 (2) June, 2018

ISSN(e): 24086851; ISSN(Print); 1119944X

http://journal.aesonnigeria.org

http://www.ajol.info/index.php/jae

Email: editorinchief@aesonnigeria.org

2. determine the perceived importance of ICT to their service delivery; and

3. determine the e-readiness of BNARDA.

\section{Methodology}

The study was carried out in Benue State. All categories of extension personnel (administrators, subject matter Specialist (SMSs), Block Extension Supervisors (BESs) \& Extension Agents (EAs)) of BNARDA constituted the population for this study (134 staff). A multi- stage sampling procedure was used to draw the sample for this study. Firstly, one administrator each was selected from each of the administrative zones making three administrators (Zonal managers), secondly, two SMSs from each zones were sampled randomly, making it a total of six SMSs and two block extension supervisors each from three zones were sampled randomly making it six (6) BESs. Thirdly, twenty extension agents were randomly selected from each of the zones; this gave a total of sixty (60) EAs. Two Information Technology managers in the BNARDA state were also purposively sampled for the study. In all, seventy-seven (77) respondents were sampled for the study.

Data were collected using two sets of questionnaire (one for administrators, SMSs and supervisors and another for extension agents). Information on the socioeconomic characteristics of the respondents were examined such as age, sex of the respondents. To determine the ICT resources (both material and human resources available): respondents were asked to indicate from a list of some internet support infrastructure and application (software) resources available to them. Some of these include e-library, electricity (National grid), internet browsers and word processing packages. The section also includes human resources (both ICT manager and user), here respondents were required to indicate the years of experience, trainings obtained.

Also the respondents were asked to indicate the perceived proficiency of these personnel and users on a 4-point Likert-type scale of very good $=4$, good $=3$, fair $=$ 2 and poor $=1$ respectively. On the users' perception of their proficiency in internet usage, the extension agents indicated by ticking yes or no on a list of internet skills to indicate if they are proficient in it. To examine the extent of access the agencies have to internet and computers available, respondents were required to indicate their perception of the extent to which ICT facilities that aid internet interaction were accessible to them on a 4-Point rating scale. In determining the perceived quality of internet and electricity available, respondents were required to indicate their assessment of the quality of power supplied in their agencies with a set of statements on the quality of power supply rated on a four-point rating scale of strongly agreed $=4$, agreed $=3$, disagree $=2$, and strongly disagree $=1$.

To determine the perceived importance of ICTs, respondents were required to indicate their perception of the importance of the ICTs on a 4-point rating scale. In ascertaining the ICT policy and regulations within the organization, respondents to rate the level of the identified policies and regulations on a 4-point rating scale. 
Creative commons User License: CC BY-NC-ND

Abstracted by: EBSCOhost, Electronic Journals Service (EJS),

Google Scholar, Journal Seek, Scientific Commons,

Food and Agricultural Organization (FAO), CABI and Scopus
Journal of Agricultural Extension

Vol. 22 (2) June, 2018

ISSN(e): 24086851; ISSN(Print); 1119944X

http://journal.aesonnigeria.org

http://www.ajol.info/index.php/jae

Email: editorinchief@aesonnigeria.org

\section{Data analysis}

Frequency, percentage and mean statistics were used to present objectives 1 to 5 , while data on e-readiness was analysed using the index as follows:

e-readiness index $=\Sigma j=1, n$ wij eij/n (implicit form) (Ifinedo, 2005)

$=\Sigma \mathrm{j}=1, \mathrm{n}$ wij W1-W5 $/ \mathrm{n}$ (implicit form)

The explicit form e-readiness $=\frac{\text { EW1W2W3w4w5 }}{\mathrm{n}}$

Where,

e-readiness: the overall e-readiness value

$\mathrm{j}$ : each of the five (5) indicators (ICT resources available, extent of access, perceived quality, perceived importance and adherence to regulations)

wij: relative weights assigned to the five (5) indicators (j)

eijindividual index score for each indicator on a scale of 1 to 4 (converted as grand mean for indicators on rating scale and converted values)

$\mathrm{n}$ : total number of measures (5) (indicators)

Based on this, an overall index for the e-readiness of BNARDA was obtained. Index Rating Scale
$0.5-1.44$
Not ready
1.45-2.44 - Barely ready
2.45- 3.44 - Ready
3.45-4.00 - Very ready

The IBM SPSS Statistics and Microsoft Excel constituted the software package used for analysis. 
Creative commons User License: CC BY-NC-ND

Abstracted by: EBSCOhost, Electronic Journals Service (EJS),

Google Scholar, Journal Seek, Scientific Commons,

Food and Agricultural Organization (FAO), CABI and Scopus
Journal of Agricultural Extension

Vol. 22 (2) June, 2018

ISSN(e): 24086851; ISSN(Print); 1119944X

http://journal.aesonnigeria.org

http://www.ajol.info/index.php/jae

Email: editorinchief@aesonnigeria.org

\section{Results and Discussion}

\section{Socioeconomic Characteristics}

Data in Table 1 shows that the majority $(54.5 \%)$ of the respondents, were between the age bracket of between 50 - 59 years while the least proportion (2.6\%) were those of them were less than 39 years of age. The average age of these respondents was about 50 years. This result shows that staff of BNARDA involved in extension services were advanced in age which is believed to negatively affect interest in ICT, this could imply that there is a need for younger staff to be employed/deployed into extension as these younger ones are expected to be more interested in ICTs and can explore the benefits more than the older ones.

Table 1 shows that the majority (59.7\%) of the respondents were male, while the remaining were female. This result is indicative of the fact that more male was involved in agricultural extension work then their female counter parts in BNARDA. Table 1 shows that the majority $(84.4 \%)$ of the respondents were married, while only $1.3 \%$ were still single. This result could also be a reflection of the respondents' ages and this implies that most of these respondents will have dependents being catered for, this might also divide both their resources and time that could be channeled towards acquiring skills and experiences in ICTs.

Table 1 reveals that the majority $(74.0 \%)$ of the respondents have HND/ First degree as their current educational level/ qualification, and the least proportion of $5.2 \%$ had higher degrees. The average number of years spent in acquiring formal education was 23 years. This result reveals that all the extension staff of BNARDA have at least an OND/NCE qualification. This could be because their entry requirement demands such. The result also implies that these respondents will require less effort to acquire ICT training since they already have a good level upon which to build.

Table 1 also shows that the majority (54.5\%) of the respondents have between 7 and 11 persons eating from the same pot in their houses, while only $6.5 \%$ of them had 17 persons and above in their household. The average household size is 10 persons per household. This implies that staff of BNARDA have large households; this could be because of the culture of extended family structure as well as large number of children within households in the state.

Table 1 shows that the majority $(57.1 \%)$ of the respondents have spent between 20 and 29 years on the work, while the BNARDA staff with between 10 and 19 years of experience were $2.6 \%$. The average years of work experience of the staff was about 28 years. This result shows that the respondents have a wealth of experience which places them in good position to respond to the questions on BNARDA and it activities and this also makes their view a true picture of what is on ground. In all the majority (77.9) of the respondent were of the extension agent work status while only $2.6 \%$ of them were IT personnel. 
Creative commons User License: CC BY-NC-ND

Abstracted by: EBSCOhost, Electronic Journals Service (EJS),

Google Scholar, Journal Seek, Scientific Commons,

Food and Agricultural Organization (FAO), CABI and Scopus
Journal of Agricultural Extension

Vol. 22 (2) June, 2018

ISSN(e): 24086851; ISSN(Print); 1119944X

http://journal.aesonnigeria.org

http://www.ajol.info/index.php/jae

Email: editorinchief@aesonnigeria.org

Table 1: Respondents' socio-economic characteristics

\begin{tabular}{|c|c|c|}
\hline Variable & $\begin{array}{c}\text { Percentage (\%) } \\
(n=77)\end{array}$ & Mean (M) \\
\hline \multicolumn{3}{|l|}{ Age (years) } \\
\hline Less than 39 years & 2.6 & \\
\hline $40-49$ years & 42.9 & 49.9 \\
\hline $50-59$ years & 54.5 & \\
\hline \multicolumn{3}{|l|}{ Sex } \\
\hline Male & 59.7 & \\
\hline Female & 40.3 & \\
\hline \multicolumn{3}{|l|}{ Marital status } \\
\hline Single & 1.3 & \\
\hline Married & 84.4 & \\
\hline Widowed & 11.7 & \\
\hline Divorced & 2.6 & \\
\hline \multicolumn{3}{|l|}{ Educational level } \\
\hline OND/NCE & 20.8 & \\
\hline HND/ First degree & 74.0 & \\
\hline Higher degrees (MSC/ Ph.D.) & 5.2 & \\
\hline Mean years spent in acquiring formal education & & 23 \\
\hline \multicolumn{3}{|l|}{ Household size (number) } \\
\hline $2-6$ & 14.3 & \\
\hline 7-11 & 54.5 & \\
\hline $12-16$ & 24.7 & 10 \\
\hline 17 and above & 6.5 & \\
\hline \multicolumn{3}{|l|}{ Years of Work experience (Years) } \\
\hline $10-19$ years & 2.6 & \\
\hline $20-29$ years & 57.1 & 28.0 \\
\hline Above 30years & 40.3 & \\
\hline \multicolumn{3}{|l|}{ Status } \\
\hline Administrators and SMSs & 19.5 & \\
\hline Extension agents & 77.9 & \\
\hline IT personnel & 2.6 & \\
\hline
\end{tabular}

\section{Availability of ICT Resources in BNARDA}

\section{ICT Infrastructure}

Table 2 shows that $97.4 \%$ of the respondents indicated that BNARDA have generating plants, while $94.8 \%$ indicated that they have building designated for ICT which is meant for staff. Also $72.7 \%$ indicated that BNARDA have computer set available to them, while $66.2 \%$ indicated that they are connected to the national grid for electricity supply. On the other hand, only $37.7 \%$ indicated that internet connection was available at BNARDA (headquarters office). The majority (58.4\%) of the respondents indicated that e-Library was available at BNARDA. The results indicate that quiet a number of the needed infrastructure for the maximization of the benefits derivable from the use of ICTs were seen to be available by the majority of the respondents. 
Creative commons User License: CC BY-NC-ND

Abstracted by: EBSCOhost, Electronic Journals Service (EJS),

Google Scholar, Journal Seek, Scientific Commons,

Food and Agricultural Organization (FAO), CABI and Scopus
Journal of Agricultural Extension

Vol. 22 (2) June, 2018

ISSN(e): 24086851; ISSN(Print); 1119944X

http://journal.aesonnigeria.org

http://www.ajol.info/index.php/jae

Email: editorinchief@aesonnigeria.org

Even at that, internet connectivity with least (37.7\%) indication of availability could pose a major limitation to accessing these benefits by BNARDA; this because the availability of every other infrastructure for the purpose of harnessing all possible benefits of ICTs will only be possible when there is good internet connectivity.

\section{Application Software}

Table 2 further indicates that greater proportion (36.4\%) of the respondents indicated that word processing software was available to them, while $29.9 \%$ indicated that presentation software (MS Power point) was available to them and $22.1 \%$ indicated that internet browsers were available to them at BNARDA.

These results imply that computer softwares were even less available than that of internet connectivity in the ICT infrastructure. Also, the software most available were those used for the basic applications of office routine duties. This is in agreement with the opinion of Richardson (2006) who was of the opinion that scanty availability or total absence of ICT tools in respondents' work places is a disadvantage to any efforts towards harnessing agricultural extension and ICT for a better effectiveness of extension work.

Table 2: ICT resources available in BNARDA

\begin{tabular}{ll}
\hline ICT Infrastructure & Percentage (\%) \\
\hline $\begin{array}{l}\text { BNARDA is currently on the national grid for electricity } \\
\text { supply }\end{array}$ & 66.2 \\
$\begin{array}{l}\text { The major electricity supply of BNARDA is sourced from } \\
\text { generator/plant }\end{array}$ & 97.4 \\
$\begin{array}{l}\text { BNARDA has buildings designated for ICT which is meant } \\
\text { for staff }\end{array}$ & 94.8 \\
$\begin{array}{l}\text { E-Library is available for use at BNARDA } \\
\text { BNARDA has computer for use }\end{array}$ & 58.4 \\
$\begin{array}{l}\text { BNARDA is connected to the internet } \\
\text { Application software }\end{array}$ & 72.7 \\
$\begin{array}{l}\text { Spread sheet such as MS excel is installed in the office } \\
\text { computer }\end{array}$ & 7.8 \\
$\begin{array}{l}\text { Word processing software (Microsoft word, note pad, word } \\
\text { pad etc) is installed in the computer }\end{array}$ & 36.4 \\
$\begin{array}{l}\text { The computer has presentation software (power point) } \\
\text { installed on it }\end{array}$ & 29.9 \\
$\begin{array}{l}\text { Graphic application software (CorelDraw, Photoshop, etc) is } \\
\text { installed on the computer }\end{array}$ & 6.5 \\
$\begin{array}{l}\text { Internet browsers (google chrome, Internet explorer etc) are } \\
\text { installed on the computer }\end{array}$ & 22.1 \\
\hline
\end{tabular}

\section{Information Technology Personnel/ Managers' IT Proficiency}

Results on Table 3 indicate that the IT personnel of BNARDA were good in all the six ICT skills of IT personnel. The result shows that they had excellent rating of 
Creative commons User License: CC BY-NC-ND

Abstracted by: EBSCOhost, Electronic Journals Service (EJS),

Google Scholar, Journal Seek, Scientific Commons,

Food and Agricultural Organization (FAO), CABI and Scopus
Journal of Agricultural Extension

Vol. 22 (2) June, 2018

ISSN(e): 24086851; ISSN(Print); 1119944X

http://journal.aesonnigeria.org

http://www.ajol.info/index.php/jae

Email: editorinchief@aesonnigeria.org

themselves on computer programming skill $(\bar{x}=3.50)$, as well as good software installations $(\bar{x}=3.00)$, hardware repair $(\bar{x}=2.50)$, internet networking $(\bar{x}=3.00)$, intranet networking $(\bar{x}=3.00)$ and software/hardware problem solving $(\bar{x}=3.00)$ skills. This result further shows a standard deviation value of 1.414 for software installation; internet and intranet networking and software/ hardware problem solving skills. This standard deviation implies that there is a disparity in the perceived IT proficiency rating to the mean score among the two IT managers. While for hardware repair and programming, the standard deviation $(S D=0.707)$ were low showing that the IT personnel were close in their perception of proficiency rating to the mean score value in these skills.

The result implies that the IT personnel possess competencies required to be IT managers and BNARDA ICT unit has cable hands who can handle the basic problems that can arise in the unit. This should make the unit perform well if given the necessary conditions of work such as good funding for subscriptions and maintenance.

Table 3: IT personnel's proficiency in ICT skills

\begin{tabular}{lcr}
\hline ICT Skills & Mean & Std. Deviation \\
\hline Software Installation & 3.00 & 1.414 \\
Hardware Repairs & 2.50 & 0.707 \\
Internet Networking & 3.00 & 1.414 \\
Intranet Networking & 3.00 & 1.414 \\
Software/Hardware Problem solving & 3.00 & 1.414 \\
Programming & 3.50 & 0.707 \\
\hline
\end{tabular}

\section{ICT Users' Proficiency in the Use of Computer}

Table 4 on the respondents' proficiency in computer usage shows that social networking via the computer $(\bar{x}=2.25)$ has the highest mean scores while the skills on power point presentation $(\bar{x}=2.00)$, e-mail operation $(\bar{x}=2.00)$ and excel spread sheet $(\bar{x}=2.00)$ followed. The skill of printing document $(\bar{x}=1.38)$ was the skill with the least mean score. The result shows that the respondents were not highly proficient in all the computer skills. The standard deviation scores show that only two computer skills had standard deviation of 0.89 while the remaining seven computer skills had standard deviations ranging from 1.05 to 1.34. Therefore, only two computer skills had respondents with individual rating close to the respective mean scores. The other seven computer skills indicate that the individual responses were not so close to the respective mean scores, showing variation of opinions as measured in the respondents' proficiency in the use of computer.

The result implies that several of the staff lack computer operation skills and there is a serious need for training of these BNARDA extension staff on the use of computer in the areas of general computer skills, micro soft word processing, power point preparation, internet browsing, email operation, social network via the computer, printing of document, excel spread sheet and the operation of photocopy machine. According to Siraj (2012), the importance of these skills to agricultural extension 
Creative commons User License: CC BY-NC-ND

Abstracted by: EBSCOhost, Electronic Journals Service (EJS),

Google Scholar, Journal Seek, Scientific Commons,

Food and Agricultural Organization (FAO), CABI and Scopus
Journal of Agricultural Extension

Vol. 22 (2) June, 2018

ISSN(e): 24086851; ISSN(Print); 1119944X

http://journal.aesonnigeria.org

http://www.ajol.info/index.php/jae

Email: editorinchief@aesonnigeria.org

service delivery are manifold as ICT contributes heavily in increasing productivity of staff, increasing work efficiencies as well as achieving economies of scale in the various aspect of extension service delivery whether it is in office documentation, communication, farmers' education, rural development service delivery, etc.

Table 4: Respondents' Proficiency in computer usage

\begin{tabular}{lcr}
\hline Computer operation skills & Mean & Std. Deviation \\
\hline General computer skills & 1.79 & 0.893 \\
MS word processing & 1.89 & 1.054 \\
Power point preparation & 1.60 & 1.342 \\
Power point presentation & 2.00 & 1.225 \\
Internet browsing & 1.86 & 1.069 \\
Email operation & 2.00 & 1.095 \\
Social networking via the computer & 2.25 & 1.258 \\
Printing documents & 1.38 & 0.885 \\
Excel spread sheet & 2.00 & 1.225 \\
Photocopy machines & 1.55 & 0.800 \\
\hline
\end{tabular}

\section{Perception of the Importance of ICT to BNARDA Extension Service Delivery}

Table 5 shows that BNARDA staff perceived that internet makes their extension service more effective $(\bar{x}=2.95)$, internet consumes their time, yet they still don't find materials they needed $(\bar{x}=2.55)$ and that they can do without the computer as it really does not improve their work $(\bar{x}=2.60)$. They do not agree with the statement that internet does not improve their service delivery $(\bar{x}=2.36)$, they find it difficult to use computer to do what they want $(\bar{x}=2.19)$ as well as learning computer will take too much of their time $(\bar{x}=1.82)$.

This result implies that though there is some importance placed on the use of ICTs in their extension service delivery, the general view shows that the staff still have low perception of the importance of ICTs for their service delivery. There is therefore a need for proper orientation of the staff of BNARDA on the place of ICTs for extension service delivery. This is because Omotayo (2005), observes that front line extension workers who become the direct link between farmers and other actors in the extension of agricultural knowledge and information systems are well positioned to make use of ICT to access expert knowledge or other types of information that could facilitate the accomplishment of the farmers' routine activities. 
Creative commons User License: CC BY-NC-ND

Abstracted by: EBSCOhost, Electronic Journals Service (EJS),

Google Scholar, Journal Seek, Scientific Commons,

Food and Agricultural Organization (FAO), CABI and Scopus
Journal of Agricultural Extension

Vol. 22 (2) June, 2018

ISSN(e): 24086851; ISSN(Print); 1119944X

http://journal.aesonnigeria.org

http://www.ajol.info/index.php/jae

Email: editorinchief@aesonnigeria.org

Table 5: Perceived importance of ICTs

\begin{tabular}{lrr}
\hline Items & Mean & \multicolumn{2}{c}{$\begin{array}{l}\text { Std. } \\
\text { Deviation }\end{array}$} \\
\hline Internet does not improve my service delivery & 2.36 & 0.842 \\
Internet makes my extension services more effective & 2.95 & 0.647 \\
$\begin{array}{l}\text { It's difficult finding materials from the internet relevant to } \\
\text { my field }\end{array}$ & 1.48 & 0.576 \\
$\begin{array}{l}\text { Internet consumes my time, yet I don't find materials I } \\
\text { need }\end{array}$ & 2.55 & 0.575 \\
I can do without the computer, it really does not add to my & 2.60 & 0.693 \\
work & 1.13 & 0.375 \\
Computer is not needful in agricultural extension services & 2.19 & 0.889 \\
I find it difficult to use computer to do what I want & 1.82 & 0.663 \\
\hline Learning computer will take too much of my time & &
\end{tabular}

\section{E-Readiness Assessment Index}

Table 6 shows the indicators of e-readiness which includes the resources available (index $=1.97$ ), the accessibility to ICT (index $=1.35$ ), respondents' perceived quality of ICTs (index $=1.69$ ) as well as perceived importance of ICTs (index $=2.14$ ). It also reveals the adherence to policies and regulations of BNARDA on ICT (index $=1.93$ ) and the e-readiness index of BNARDA (index=1.82). The e-readiness indicator of BNARDA on resources available shows the respondents' indices, with the highest index (3.0) as the human managers (IT personnel), this was followed by the infrastructure available (1.93), and then human ICT users (1.02). This result means that among the various components of resources available, human managers (IT personnel) were the most available resource to BNARDA. This could be as a result of the high competence and training levels of the IT personnel. The implication of this is that though BNARDA has good IT personnel, not much can be done since there are limitations in the availability of infrastructure with which to exercise those skills and training by the managers. Also, the poor availability of infrastructure and human users could be as a result of the poor funding experienced by the ADPs after the withdrawal of World Bank assistance.

Access to ICT by users is also one of the indicators of e-readiness, and the result on Table 6 reveals that the respondents' rating of their access to ICT is low $(\bar{x}=1.35)$. This low access to ICT by BNARDA could be as a result of their poor ICT knowledge of its uses as well as the poor availability of infrastructure. This implies that BNARDA staff do not enjoy the various benefits available in the electronic world. Wikipedia (2009) stated that any system used for getting information and knowledge for making decisions in any industry (agricultural extension inclusive) should deliver accurate, complete, concise information on time; and that the information provided by the system must be in user-friendly form, easy to access and cost-effective. Such delivery is not realizable where ICTs are not readily accessible. 
Creative commons User License: CC BY-NC-ND

Abstracted by: EBSCOhost, Electronic Journals Service (EJS),

Google Scholar, Journal Seek, Scientific Commons,

Food and Agricultural Organization (FAO), CABI and Scopus
Journal of Agricultural Extension

Vol. 22 (2) June, 2018

ISSN(e): 24086851; ISSN(Print); 1119944X

http://journal.aesonnigeria.org

http://www.ajol.info/index.php/jae

Email: editorinchief@aesonnigeria.org

Also, the table shows the e-readiness indicator of BNARDA on respondents' perception of the quality of ICTs which include their perceptions of quality of electricity $(\bar{x}=1.90)$, quality of internet $(\bar{x}=1.89)$ and quality computers $(\bar{x}=1.29)$. This result reveals that the respondents perceived the quality of ICTs in BNARDA as being poor. This implies that the available ICTs may not be able to serve the current needs and advancement in ICT use. There is therefore, the need for BNARDA to improve the quality of their ICTs, because the e-world is an ever evolving one.

The indicator $(\bar{x}=2.14)$ of e-readiness on perceived importance of ICT reveals that there is a low perception among the respondents of the importance of ICT. This could be as a result of the respondents' poor ICT knowledge; as poor knowledge limits their awareness of the possible benefits and usefulness of these ICTs to their work as extension service providers. This implies that respondents might not have been giving the needed attention to ICT trainings for the acquisition of needed skills.

Adherence to ICT policies and regulations in BNARDA as shown in Table 6 reveals 'a below average' performance $(\bar{x}=1.93)$ on a scale of 4 . This could be because of the possible attitude of the BNARDA staff to ICTs since they have a low perception of its importance to them and their work. This could also be as a result of the poor level of the ICT users in ICT usage. The implication of this is that the existing ICT policies and regulations of BNARDA are not improving the staff usage of ICTs.

The overall e-readiness index of the BNARDA (1.82) shows that the agency is barely ready for maximization of the ICTs. Since the benefits that arises from ICT is dependent on the degree to which such an agency is ready, willing or prepared to obtain these benefits. This result agrees with that of Akinbile (2010), who found that extension agents in Imo state were rarely e-ready to enjoy benefits from ICT. This result shows that the BNARDA might not be able to access the benefits available in the electronic world such as cost effectiveness in service delivery. Annor-Frempong et al (2006) noted that electronic technologies are increasingly being seen as costeffective and as practical tools to facilitate information delivery and knowledge sharing among farmers, extension agents and other stakeholders. Also, there will be increased impact by the available extension agents in service delivery as better information will be obtained and more farmers reached by these agents. 
Creative commons User License: CC BY-NC-ND

Abstracted by: EBSCOhost, Electronic Journals Service (EJS),

Google Scholar, Journal Seek, Scientific Commons,

Food and Agricultural Organization (FAO), CABI and Scopus
Journal of Agricultural Extension

Vol. 22 (2) June, 2018

ISSN(e): 24086851; ISSN(Print); 1119944X

http://journal.aesonnigeria.org

http://www.ajol.info/index.php/jae

Email: editorinchief@aesonnigeria.org

Table 6: E- readiness index of BNARDA

\begin{tabular}{|c|c|c|c|c|c|c|}
\hline $\begin{array}{l}\text { Indicators } \\
\text { of e- } \\
\text { readiness }\end{array}$ & $\begin{array}{l}\text { Sub } \\
\text { components } \\
\text { of } \\
\text { indicators }\end{array}$ & $\begin{array}{l}\text { Sub-sub } \\
\text { components } \\
\text { of } \\
\text { indicators }\end{array}$ & $\begin{array}{l}\text { Means of } \\
\text { Sub-sub } \\
\text { components } \\
\text { of } \\
\text { indicators }\end{array}$ & $\begin{array}{l}\text { Mean of Sub } \\
\text { components } \\
\text { of } \\
\text { indicators }\end{array}$ & $\begin{array}{l}\text { Means of } \\
\text { indicators } \\
\text { of } \mathrm{e}- \\
\text { readiness }\end{array}$ & Index \\
\hline \multirow[t]{3}{*}{$\begin{array}{c}\text { Resources } \\
\text { available }\end{array}$} & $\begin{array}{l}\text { Infrastructure } \\
\text { available }\end{array}$ & & & 1.93 & 1.97 & \\
\hline & Human & Managers & 3.0 & 2.01 & & \\
\hline & & Users & 1.02 & & & \\
\hline $\begin{array}{l}\text { Access to } \\
\text { ICT }\end{array}$ & & & & & 1.35 & \\
\hline \multirow{3}{*}{$\begin{array}{l}\text { Perceived } \\
\text { quality of } \\
\text { IT }\end{array}$} & & & & 1.90 & 1.69 & 1.816 \\
\hline & Internet & & & 1.89 & & \\
\hline & Computers & & & 1.29 & & \\
\hline $\begin{array}{l}\text { Importance } \\
\text { of ICT }\end{array}$ & & & & & 2.14 & \\
\hline $\begin{array}{l}\text { Adherence } \\
\text { to policies } \\
\text { and } \\
\text { regulations }\end{array}$ & & & & & 1.93 & \\
\hline
\end{tabular}

\section{Conclusion and Recommendations}

BNARDA has ICT infrastructure but they are poor in application software. There are well trained IT personnel who have work experiences. The perception of the extension workers on the importance of ICT to their work is also low and they are barely e-ready. Therefore, the public extension workers have limited preparation to participate in the information age.

The Benue State government should employ more IT personnel with at least one in each agricultural zone who will be responsible for the ICT unit and train staff of the BNARDA. The government and managing agencies should make the office computers functional and ensure that official communication among personnel should be carried out using e-mails. Extension personnel are encouraged to be engage more in the use of ICTs as to enhance their capabilities and experience in the use and possible benefits derivable from it. 
Creative commons User License: CC BY-NC-ND

Abstracted by: EBSCOhost, Electronic Journals Service (EJS),

Google Scholar, Journal Seek, Scientific Commons,

Food and Agricultural Organization (FAO), CABI and Scopus
Journal of Agricultural Extension

Vol. 22 (2) June, 2018

ISSN(e): 24086851; ISSN(Print); 1119944X

http://journal.aesonnigeria.org

http://www.ajol.info/index.php/jae

Email: editorinchief@aesonnigeria.org

\section{References}

Akinbile L. A. (2010) Assessment of e-readiness of extension agents in agricultural information dissemination in Imo state, Nigeria Retrieved on $13^{\text {th }}$ may 2013 from http://www.ajol.info/index.php/gaep/article/view/50145

Asian Pacific Economic Cooperation (APEC), (2000). The APEC e-commerce readiness assessment guide. Retrieved from http://www.ecommerce.gov/apec/docs/readiness_guide_files/readiness_guide _5pdf

Annor-frempong, F., Kwarteng, J, Agunga, R. \& Zinnah, M.M. (2006). Challenges and Prospects Infusing Information Communication Technologies (ICTs) in Extension for Agricultural and Rural Development in Ghana, AIAEE 22nd Conference proceedings.

Belize National ICT Policy (2007). E-readiness Assessment September, 2007. Available on https://nurhadiw.files.wordpress.com/2010/08/e-readinessquestionnaire.pdf retrieved, September, 2014.

Benue Agricultural and Rural Development Authority (BNARDA) (2005). Implementation, completion report on National Special Programme for Food Security (NSPFS), Benue State.

Computer System Policy Project's (CSPP), (1998). The CSPP readiness guide for living in the networked world. Retrieved from www.cspp.org

Dada, D. (2006). E-readiness for developing countries: moving the focus from the environment to the users. London school of economics and political science 27(6), 1-14

Ifinedo, P. (2005). Measuring Africa's e-readiness in the global networked economy: A nine-country data analysis. International Journal of Education and Development using Information and Communication Technology (IJEDICT), $1(\mathrm{I})$, 53-71.

Ogbonna, E.E. (2011). Availability, access and utilization of information communication technologies among staff of women in agriculture subprogramme of agricultural development programmes in north central zone of Nigeria. An M.Sc. Project submitted to the Department of Agricultural Extension University of Nigeria Nsukka.

Olaolu, M.O. (2011). Impacts of the Fadama development project on poverty reduction and food security among rice farmer beneficiaries in Kogi State Nigeria. An M.Sc. Project submitted tothe Department of Agricultural Extension University of Nigeria Nsukka.

Omotayo, O.M. (2005). ICT and agricultural extension. Emerging issues in transferring agricultural technology in developing countries. In S.F. Adedoyin, (ed.), Agricultural Extension in Nigeria. Ilorin, Agricultural Extension Society of Nigeria. 
Creative commons User License: CC BY-NC-ND

Abstracted by: EBSCOhost, Electronic Journals Service (EJS),

Google Scholar, Journal Seek, Scientific Commons,

Food and Agricultural Organization (FAO), CABI and Scopus
Journal of Agricultural Extension

Vol. 22 (2) June, 2018

ISSN(e): 24086851; ISSN(Print); $1119944 X$

http://journal.aesonnigeria.org

http://www.ajol.info/index.php/jae

Email: editorinchief@aesonnigeria.org

Richardson, D. (2006). How can agricultural extension best harness ICTs to improve rural livelihoods in developing countries? Retrieved on $5^{\text {th }}$ September, 2009 from http://developments:agi.huji.ac.il/economies/gelp-haw-ii.pdf

Siraj M. (2012). A model for ICT based services for agriculture extension in Pakistan

Zaied, A.N.H., Khairalla, F.A., \& Al-Rashid, W. (2007). Assessing e-Readiness in the arab countries: perceptions towards ICT environment in public organisations in the state of Kuwait. The Electronic Journal of e-Government, 5(1)77 - 86. Retrieved from www.ejeg.com 